論文

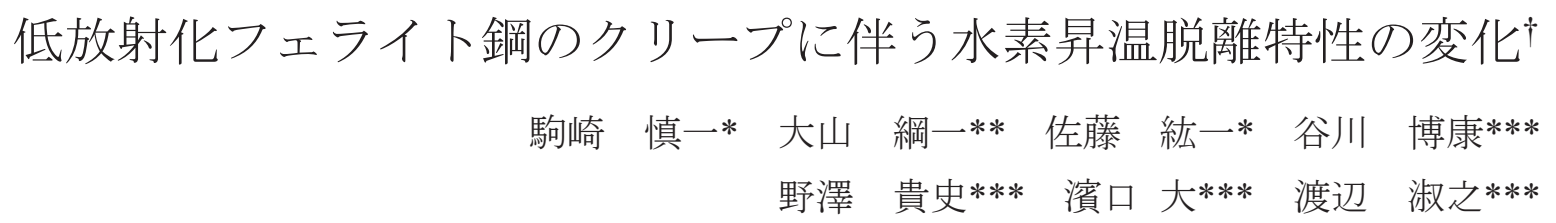

\title{
Change in Hydrogen Thermal Desorption Characteristic of Reduced Activation Ferritic/Martensitic Steel with Creep
}

by

\author{
Shin-ichi Komazaki*, Tsunakazu Ohyama**, Koichi Sato*, Hiroyasu Tanigawa***, \\ Takashi Nozawa***, Dai Hamaguchi*** and Yoshiyuki Watanabe***
}

The change in hydrogen thermal desorption characteristic of reduced activation ferritic/martensitic (RAFM) steel for fusion reactor blanket due to creep was investigated to examine the applicability of thermal desorption analysis (TDA) to remaining-life assessment. The hydrogen charging into creep damaged specimens was conducted by means of cathodic electrolysis. The hydrogen-charged samples were subjected to the TDA for the measurement of hydrogen evolution curve. The experimental results revealed that the evolution curve was changed only by creep depending on the test conditions, and the amount of hydrogen desorbed during the analysis $\left(C_{\mathrm{H}}\right)$ increased with increasing the creep life consumption. A vacancy-type defect and dislocation, which were introduced by the electron beam irradiation and the cold rolling respectively, had a large influence on the desorption characteristic, but they were by no means causes of the change in desorption characteristic with creep. It was also found that the $C_{\mathrm{H}}$ was successfully arranged with the parameter derived based on the creep void growth's law, irrespective of test conditions. The results obtained in this study indicated that the TDA could be a strong tool for the creep damage detection and remaining-life assessment of RAFM steel.

\section{Key words:}

Creep, Remaining-life, Reduced activation ferritic/martensitic steel, Fusion reactor, Blanket, Hydrogen, Thermal desorption analysis

\section{1 緒 言}

核融合炉用構造材料には, 而照射損傷特性, 低誘導放射 化特性, クリープに代表される優れた高温強度特性が求 められ, 低放射化フェライト鋼や $\mathrm{SiC} / \mathrm{SiC}$ 複合材料, バナ ジウム合金などが候補材として挙げられている ${ }^{1)-5)}$. 中で も低放射化フェライト鋼はその優れた総合性能が実証さ れてきた材料であり，工業的実績も比較的豊富である. そ のため, 冷却チャンネル付第一壁など原型炉ブランケッ トでもっとも過酷な環境下で使用される材料として期待 されている. 低放射化フェライト鋼は, ラスマルテンサイ 卜組織に加えて，W による固溶強化，MX による分散強 化, Laves 相の析出強化などにより卓越した高温強度を実 現している．可動転位に対して障壁の役割を果たす粒界 には，ラス境界やブロック粒界，パケット粒界，旧 $\gamma$ 粒界 がある.しかし, 種々のミクロ組織因子が階層的に重畳し ているため, 強度発現や劣化・損傷のメカニズムも複雑で あり，その詳細については未だ解明されていない点も多 く残されている.
陰極電解法などで鋼中に添加した水素は，空孔や空孔 クラスター, 転位, 粒界などの格子久陥や析出物, キャビ ティ, き裂などに捕獲される. 昇温により水素は外部へ放 出されるが, 久陥やミクロ組織の性状に応じて昇温過程 での水素放出特性は変化する. この昇温時の加熱温度と 水素放出速度の関係から材料中の水素の存在状態を評価 寸るのが昇温脱離分析法 (TDA: Thermal Desorption Analysis） のである. 著者らは， ボイラ用構造材料の劣化・ 損傷検出への TDA の適用性を検討するため, 高 $\mathrm{Cr}$ フェ ライト系而熱鋼の母材 7) や溶接継手部 ${ }^{8}$ の水素昇温脱離特 性を調查した. その結果, 単純加熱時効では変化しない水 素チャージ後の水素放出量がクリープの進行とともに増 加することをはじめて明らかにした。

本研究では, 核融合炉ブランケット第一壁のクリープ 余寿命評価への TDA の適用性を検討することを目的とし て, 低放射化フェライト鋼 $\mathrm{F} 82 \mathrm{H}$ のクリープに伴う水素 昇温脱離特性の変化を調べた. また, 水素昇温脱離特性変 化の要因解明の一環として, 電子線照射材と冷間圧延材

$\dagger$ 原稿受理 令和2年7月10日 Received July 10, 2020 @2021 The Society of Materials Science, Japan

* 正 会 員 鹿児島大学学術研究院理工学域工学系 T890-0065 鹿児島市郡元

Research Field in Engineering, Science and Engineering Area, Research and Education Assembly, Kagoshima University, Korimoto, Kagoshima, 890-0065.

** 学生会員 鹿児島大学大学院理工学研究科 †890-0065 鹿児島市郡元

Graduate School of Science and Engineering, Kagoshima University, Korimoto, Kagoshima, 890-0065.

*** 量子科学技術研究開発機構 $\bar{T} 039-3212$ 青森県上北郡六ヶ所村大字尾駮字表舘

National Institutes for Quantum and Radiological Science and Technology, Rokkasho, Kamikita-Gun, Aomori, 039-3212 
Table 1 Chemical compositions (wt $\%$ ) and heat treatment of $\mathrm{F} 82 \mathrm{H}$.

\begin{tabular}{|c|c|c|c|c|c|c|c|c|c|c|c|}
\hline $\mathrm{C}$ & $\mathrm{Si}$ & $\mathrm{Mn}$ & $\mathrm{Cr}$ & $\mathrm{W}$ & $\mathrm{V}$ & $\mathrm{Ta}$ & $\mathrm{Al}$ & $\mathrm{N}$ & $\mathrm{Ti}$ & $\mathrm{B}$ & $\mathrm{Fe}$ \\
\hline 0.09 & 0.11 & 0.16 & 7.71 & 1.95 & 0.16 & 0.02 & 0.003 & 0.007 & 0.004 & 0.0002 & bal. \\
\hline
\end{tabular}

Table 2 Creep test conditions and results.

\begin{tabular}{|c|c|c|c|}
\hline $\begin{array}{c}\text { Temp. } \\
\left({ }^{\circ} \mathrm{C}\right)\end{array}$ & $\begin{array}{c}\text { Stress } \\
(\mathrm{MPa})\end{array}$ & $\begin{array}{c}\text { Time } \\
(\mathrm{h})\end{array}$ & $\begin{array}{c}\text { Life fraction, } \\
(\%)\end{array}$ \\
\hline 675 & 40 & 9149 & 100 \\
\hline 650 & 60 & 9435 & 100 \\
\hline \multirow{3}{*}{600} & \multirow{3}{*}{100} & 5091 & 20 \\
\cline { 3 - 4 } & & 10182 & 40 \\
\cline { 3 - 4 } & & 15594 & 60 \\
\cline { 3 - 4 } & \multirow{3}{*}{140} & 25454 & 100 \\
\cline { 3 - 4 } & & 1053 & 40 \\
\cline { 3 - 4 } & & 1843 & 70 \\
\hline \multirow{3}{*}{550} & \multirow{3}{*}{170} & 2608 & 100 \\
\cline { 3 - 4 } & & 1582 & 30 \\
\cline { 3 - 4 } & & 12636 & 50 \\
\cline { 3 - 4 } & & 25272 & 100 \\
\hline
\end{tabular}

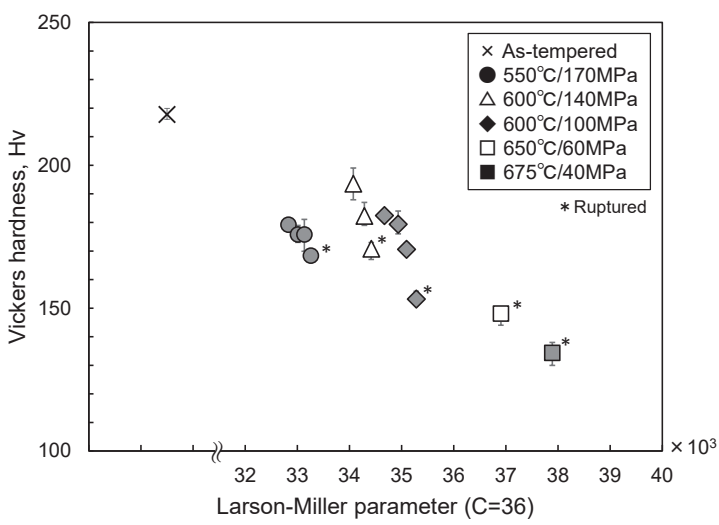

Fig. 1 Change in Vickers hardness with creep.

を用いて水素昇温脱離特性に及ぼす格子欠陥の影響を調 査した。 さらには, 著者らが提案しているキャビティ成長 則に基づいたパラメータ 9)を用いたクリープ余寿命評価 についても検討した。

\section{2 供試材および試験方法}

\section{$2 \cdot 1$ 供試材およびクリープ損傷付与条件}

供試材として，低放射化フェライト鋼 F82H IEA heat を 用いた。同鋼の化学組成と熱処理条件を Table 1 に示寸. 同鋼を用いて, $550^{\circ} \mathrm{C} / 170 \mathrm{MPa}, 600^{\circ} \mathrm{C} / 140 \mathrm{MPa}, 600^{\circ} \mathrm{C} / 100$ $\mathrm{MPa}, 650^{\circ} \mathrm{C} / 60 \mathrm{MPa}, 675^{\circ} \mathrm{C} / 40 \mathrm{MPa}$ の試験条件下でクリ ープ破断試験とクリープ中断試験を実施し，損傷度の異 なる種々のクリープ損傷材を作製した. クリープ損傷付 与条件をまとめたものを Table 2 に示す.

\section{$2 \cdot 2$ 水素昇温脱離分析 (TDA)}

TDA 用試料として，小さな薄板状試料（例えば， $5 \times 5.5 \times 0.5 \mathrm{~mm})$ をクリープ試験片のゲージ部およびグリ
ップ部より切り出した. 試料サイズはクリープ試験片に 応じて幾分異なるものの, 板厚は水素昇温脱離特性に大 きく影響するため, 湿式研磨によりすべて $0.5 \pm 0.005 \mathrm{~mm}$ の精度で調整した. なお, 表面仕上げは\#2400の耐水研磨 紙で行った.

水素チャージは，触媒毒として $\mathrm{NH}_{4} \mathrm{SCN}$ を 0.5 mass\% 添加した $0.1 \mathrm{~mol} / \mathrm{L} \mathrm{NaOH}$ 水溶液中 $\left(30^{\circ} \mathrm{C}\right)$ にて, 電流密 度 : $5 \mathrm{~mA} / \mathrm{cm}^{2}$, チャージ時間 : $4 \mathrm{~h}$ の条件下にて陰極電解 法によって行った. チャージ後, 昇温加熱機構付きガスク ロマトグラフを用いて水素放出曲線を測定した．チャー ジ終了から分析までの時間は 5 min と統一した. キャリア ガスとして $\operatorname{Ar}\left(1.2 \times 10^{-5} \mathrm{~m}^{3} / \mathrm{min}\right)$ を用い, 昇温速度 : $100^{\circ} \mathrm{C} / \mathrm{h}$, 測定温度範囲 : 室温 室温 $+250^{\circ} \mathrm{C}$ のもと, 放出 された水素の量を $5 \mathrm{~min}$ に一度の間隔で計測した. 単位時 間当たりの水素放出量を試料質量で除して水素放出速度 を算出し，水素放出曲線を求めた.

\section{3 結果および考察}

\section{$3 \cdot 1$ クリープ損傷材の硬さとミクロ組織}

クリープ損傷材で計測されたビッカース硬さを，前報 9) と同様, 定数 $\mathrm{C}=36^{10)}$ の Larson-Miller パラメータ (LMP) に対してプロットしたものを Fig. 1 に示す. 同図からわか るように, 焼戻しまま材 (図中×印) に比べクリープ損傷 材の硬さは低く, その減少量は低応力長時間側ほど顕著

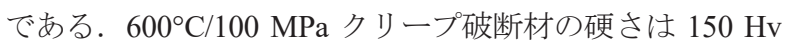
と焼戻しまま材に比べ $70 \mathrm{Hv}$ 程度も減少していた。

ミクロ組織観察結果の一例として, $600^{\circ} \mathrm{C} / 100 \mathrm{MPa}$ クリ 一プ破断材の SEM 像を Fig. 2 に示す. 典型的なマルテン サイト組織に加え, $\mathrm{MX}$ や $\mathrm{M}_{23} \mathrm{C}_{6}$ と思われる析出物がブロ ック粒界やパケット粒界, 旧 $\gamma$ 粒界に沿って析出してい るのが観察された．析出物は焼戻しまま材に比べ大きく, 転位組織の回復に加え析出物の粗大化もクリープに伴う 軟化の要因であると考えられた. また, 同図に示すように, 旧 $\gamma$ 粒界近傍で発生したと思われる比較的大きなキャビ ティも観察された。

\section{$3 \cdot 2$ クリープに伴う水素昇温脱離特性の変化}

水素昇温脱離分析結果の例として, $600^{\circ} \mathrm{C} / 100 \mathrm{MPa}$ クリ ープ損傷材で計測された水素放出曲線を Fig. 3 に示す. 焼 戻しまま材のピーク温度が $50^{\circ} \mathrm{C}$ 程度であるのに対して,

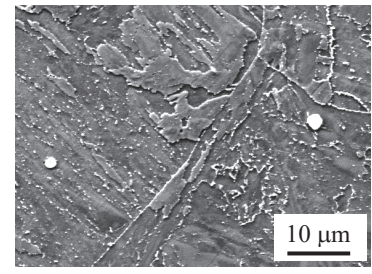

(a) As-tempered

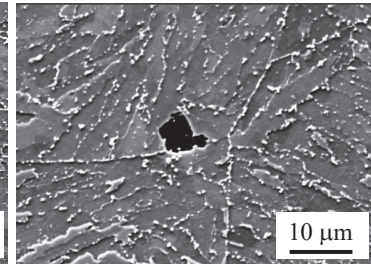

(b) Ruptured $\left(600^{\circ} \mathrm{C} / 100 \mathrm{MPa}\right)$
Fig. 2 SEM micrographs of F82H. 


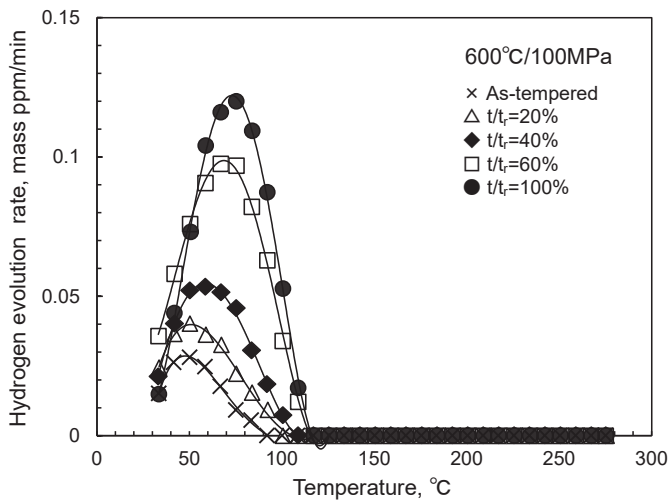

Fig. 3 Change in hydrogen evolution curve due to creep damage $\left(600^{\circ} \mathrm{C} / 100 \mathrm{MPa}\right)$.

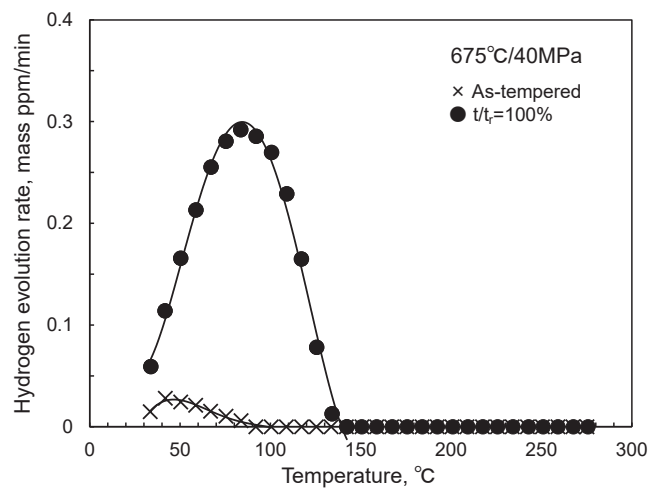

Fig. 4 Change in hydrogen evolution curve due to creep damage $\left(675^{\circ} \mathrm{C} / 40 \mathrm{MPa}\right)$

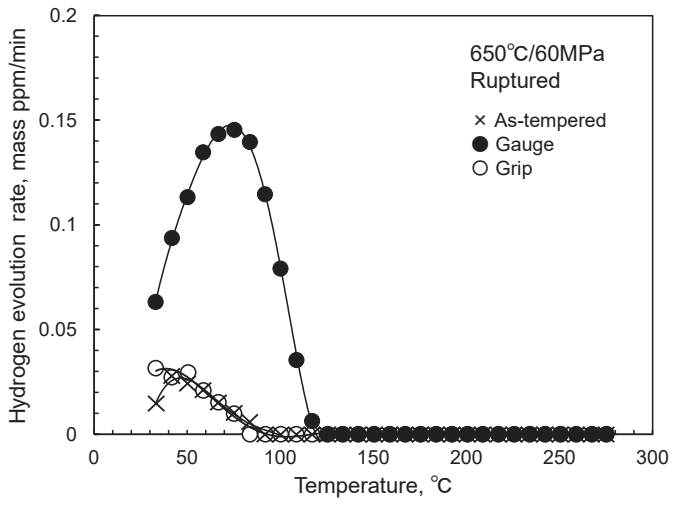

Fig. 5 Hydrogen evolution curves measured on gauge and grip portions of ruptured specimen $\left(650^{\circ} \mathrm{C} / 60 \mathrm{MPa}\right)$.

クリープ損傷材のそれは寿命消費に伴い徐々に高くなり， クリープ破断材に至っては $75^{\circ} \mathrm{C}$ 程度と大きく高温側にシ フトしている.さらに, ピーク高さについても, 焼戻し時 0.03 mass $\mathrm{ppm} / \mathrm{min}$ であったものがクリープ損傷の進行と ともに上昇し，破断時には $0.12 \mathrm{mass} \mathrm{ppm} / \mathrm{min}$ と 4 倍にま で増加している. $675^{\circ} \mathrm{C} / 40 \mathrm{MPa}$ クリープ破断材において は，その上昇は 10 倍程度にもなった（Fig. 4)。

$650^{\circ} \mathrm{C} / 60 \mathrm{MPa}$ クリープ破断材のゲージ部とグリップ部 で計測された水素放出曲線を, 焼戻しまま材のものと併
せて Fig. 5 に示す. 前述したように, ゲージ部においては ピーク高さが上昇し, ピーク温度も高温側にシフトして いる. 一方, 加熱時効のみであるグリップ部では顕著な変 化はなく, 焼戻しまま材の曲線とほぼ一致している.この ような結果は，他の試験条件のグリップ部でも同様であ った. 得られた結果は, 水素昇温脱離特性の変化が加熱時 効によるミクロ組織性状の変化 (例えば, 析出物の新たな 析出や粗大化) に起因寸るものではなく, 応力負荷下で生 じる現象すなわちクリープ損傷を反映していることを示 唆している.

水素放出曲線下の面積から分析中に放出された水素の 量を算出し, 水素放出量 $C_{\mathrm{H}}$ とした. クリープ損傷材で得 られた $C_{\mathrm{H}}$ の対数をLMP で整理したものが Fig. 6 である. 試験条件に応じてその挙動は異なるものの, いずれの場 合もクリープの進行 (寿命消費) とともに $C_{\mathrm{H}}$ は単調に増 加している. また, クリープ破断材 (図中*印の付いたデ 一夕点）の結果をみると, 低応力長時間側のものほど $C_{\mathrm{H}}$ の増加が顕著であることがわかる. これは, 高応力短時間 側での破壊の主たる原因が変形であるのに対して，低応 力長時間側ではそれがキャビティや粒界すべりなどの機 械的損傷に変化するためである.

\section{$3 \cdot 3$ 水素昇温脱離特性に及ぼす格子欠陥の影響}

水素放出曲線変化の機序解明の一環として, 水素昇温 脱離特性に及ぼす格子欠皕の影響について調べた。具体 的には, 空孔型欠陥と転位を導入した試料を作製し，それ らの水素昇温脱離特性を調查した。

空孔型欠陥は, 微小薄板状試料 $(5 \times 10 \times 0.5 \mathrm{~mm})$ を用 いて電子線照射によって導入した。 京都大学複合原子力 科学研究所の電子線型加速器を用いて, 電子を $8 \mathrm{MeV}$ ま で加速し, 照射量 : $2.18 \times 10^{27} / \mathrm{m}^{2}$, 照射温度 : $60 \pm 10^{\circ} \mathrm{C}$ の条件で照射した。損傷は板厚方向全体に導入されてお り，その量ははじき出しのしきいエネルギーを $40 \mathrm{eV}$ とし て $1.39 \times 10^{-4} \mathrm{dpa}$ と見積もられた ${ }^{11)}$. 照射材で計測された 水素放出曲線の例を Fig. 7 に示寸. 同図には照射材の 1 回 目の計測結果（図中@印）に加え，1回目の計測が終了し た後に改めて水素チャージを行い再度計測した結果（図 中○印）を示してある. 焼戻しまま材と 1 回目の結果を比

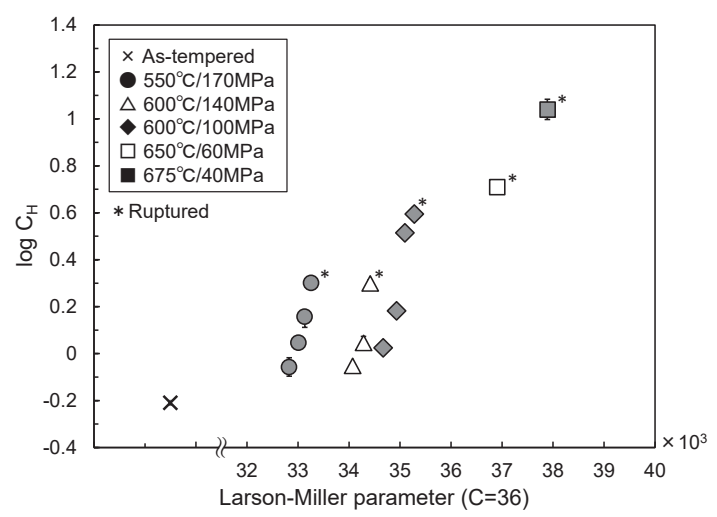

Fig. 6 Change in $C_{\mathrm{H}}$ with creep damage accumulation. 


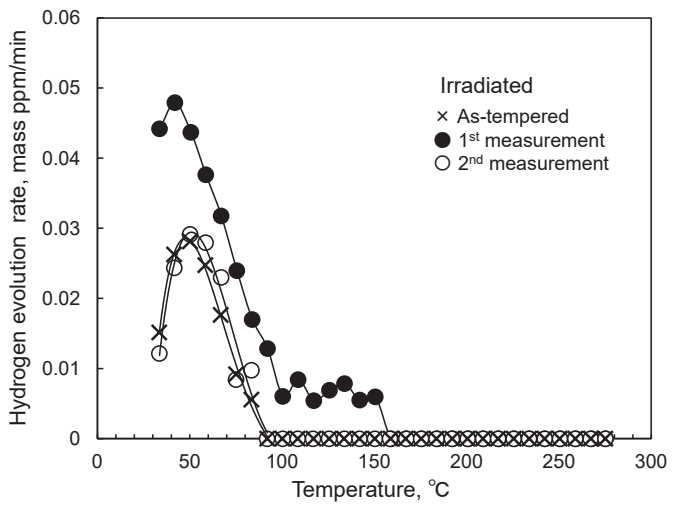

Fig. 7 Effect of electron beam irradiation on hydrogen thermal desorption characteristic.

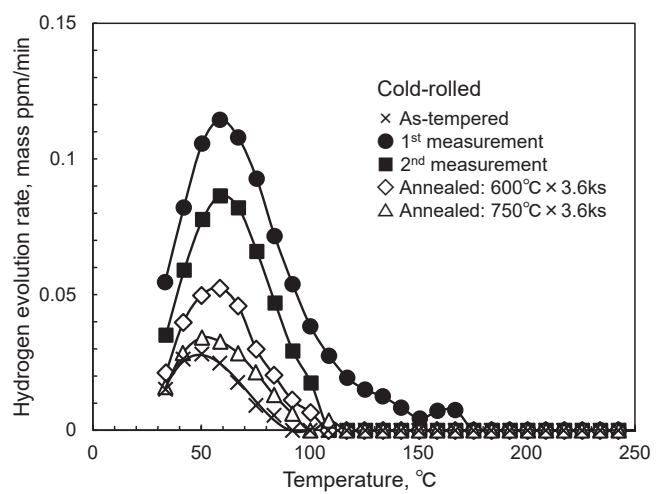

Fig. 8 Effect of cold rolling on hydrogen thermal desorption characteristic.

較すると，ピーク温度にほとんど差はないが，ピーク高さ は照射によって上昇している。また， $100 \sim 150^{\circ} \mathrm{C}$ で焼戻 しまま材にはみられない新たな水素の放出が明瞭に観察 される.しかし，2回目の計測ではこのような照射の影響 は消え，水素放出曲線は焼戻しまま材のものと完全に一 致した. このような变化は, 導入された久陥が 1 回目の計 測の際の昇温過程で消滅したためである ${ }^{12}$ )。得られた結 果は, クリープに伴う水素昇温脱離特性の変化が, 電子線 照射で導入されるようなタイプの欠陥によるものではな いことを意味している．クリープ損傷材の水素放出曲線 は, 2 回目以降の計測でわずかにピーク高さは減少するも のの，焼戻しまま材の曲線とは一致しないためである ${ }^{13)}$. なお, 今回の照射によって導入された空孔の濃度は $10^{-6}$ 才 一ダーと見積もられた ${ }^{14)}$ 。室温における熱平衡空孔濃度 は $10^{-25}$ オーダーであり ${ }^{15)}$ ，照射で導入された濃度と比心 るとゼロとみなせるほど小さい, つまり，1 回目と 2 回目 の $C_{\mathrm{H}}$ の差 0.9 mass ppm が $10^{-6}$ オーダーの空孔型欠陥に捕 獲されて（と相互作用して）いた水素の量ということにな る.

転位は冷間圧延によって導入した，圧下率を $28 \%$ とし， 圧延後に板厚 $0.5 \mathrm{~mm}$ の薄板に加工し TDA 用試料とした. 一部の圧延材については, 久陷量の減少を目的として, 圧 延後 $600^{\circ} \mathrm{C}$ と $750^{\circ} \mathrm{C}$ にて $3.6 \mathrm{ks}$ の焼なまし処理を行った.
圧延材で計測された水素放出曲線を Fig. 8 亿示寸. 同図に は, 圧延まま材を 2 回計測した結果に加え，焼なまし材の 結果も示している，圧延まま材の 1 回目の結果（図中 印）から，ピーク温度はあまり変化しないが，ピーク高さ が焼戻しまま材 (図中×印) に比べ 4 倍程度増えているの がわかる. しかし, 2 回目の計測ではピーク高さは減少し, $100^{\circ} \mathrm{C}$ 以上にみられた水素放出も大きく減少もしくは消 滅している (図中四印)。圧延によって硬さはわずかに増 加し $230 \mathrm{Hv}$ 程度になったが， 1 回目の計測後も硬さに変 化がなかったことから, 1 回目の昇温過程では転位組織の 回復は生じなかったと思われる.すなわち, 2 回目でピー ク高さが減少したのは, 前述した理由と同じで, 圧延で転 位とともに導入された空孔型欠陥が 1 回目の昇温過程で 減少したためである。同図からわかるように, $600^{\circ} \mathrm{C}$ と $750^{\circ} \mathrm{C}$ の焼なましによってピーク高さは顕著に減少し, $750^{\circ} \mathrm{C}$ 焼なまし材ではほぼ焼戻しまま材のレベルにまで 戻っている. 焼なまし後の硬さはそれぞれ $220 \mathrm{Hv}, 200 \mathrm{Hv}$ と圧延まま材に比心低下していることから，ピーク高さ の減少は主として転位密度の減少を反映している，得ら れた結果は, 転位組織性状は水素昇温脱離特性に大きく 影響するものの, 転位密度の減少にもかかわらずピーク 高さが上昇するクリープ損傷材の結果を, 転位組織性状 の観点からは説明できないことを意味している.

このように, クリープに伴う水素昇温脱離特性の変化 は, ミクロ組織の変化 (例えば, 析出物の新たな析出や粗 大化), 空孔型欠陷や転位組織といった欠樎性状の変化に よるものではなかった．結晶粒界も水素と相互作用する ことが知られているが, 今回は顕著な粒径の変化がないこ とから, 水素昇温脱離特性に及ぼす粒界の影響は無視でき るものと思われた. また, ボイラ用 $\mathrm{Gr} .91$ 鋼 7においては, $1050^{\circ} \mathrm{C} \times 30 \mathrm{~min}$ の再焼ならしを施してもクリープ損傷材 の水素昇温脱離特性はもとに戻らなった。このことから も, クリープ損傷材における水素昇温脱離特性の変化は, 熱処理では回復しないような損傷, 寸なわち, 粒界す心゙り に起因した微小き裂や粒界キャビティ，粒内キャビティ など機械的損傷 16) と関係しているものと推測される。し かし，その詳細な検討は今後の課題であり，キャビティ内

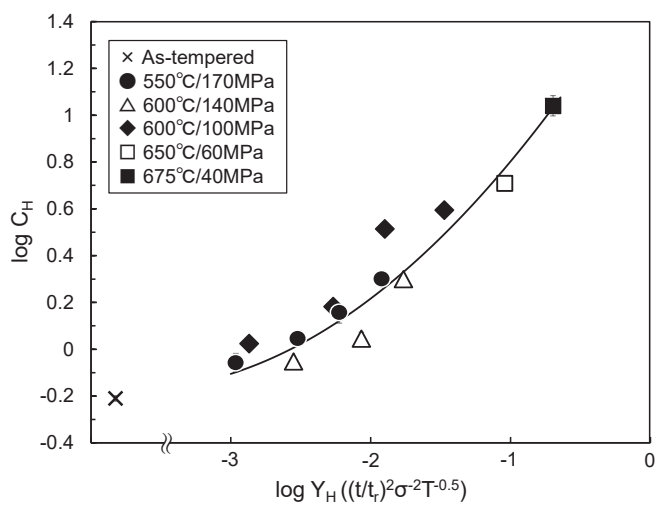

Fig. $9 C_{\mathrm{H}}$ plotted as a function of newly proposed $Y_{\mathrm{H}}$ parameter. 


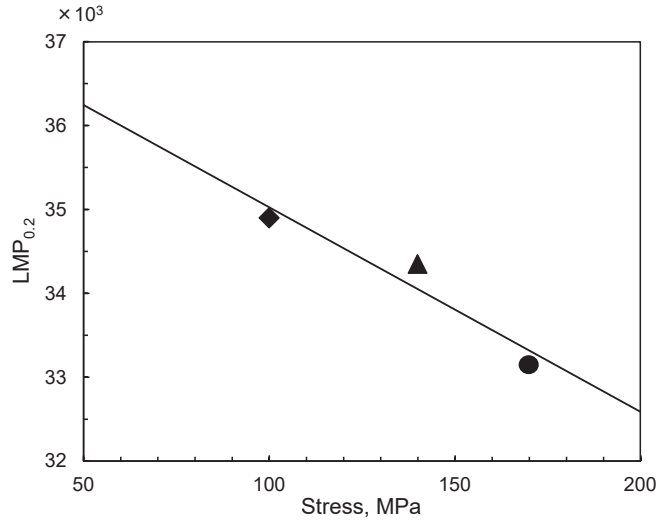

Fig. $10 \mathrm{LMP}_{0.2}$ plotted as a function of applied creep stress.

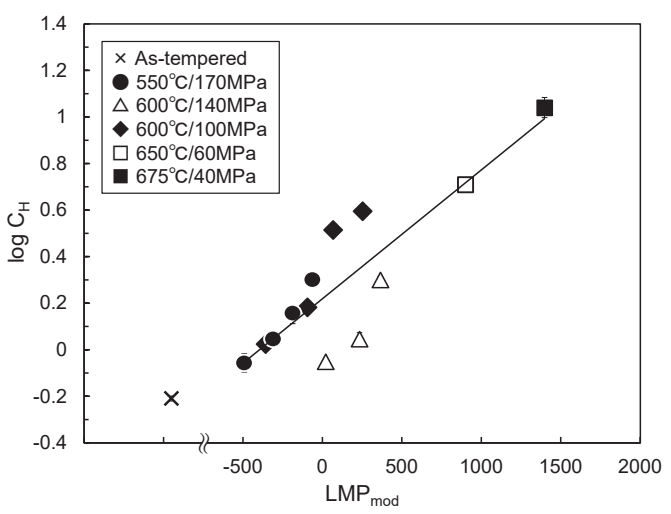

Fig. $11 C_{\mathrm{H}}$ plotted as a function of $\mathrm{LMP}_{\text {mod. }}$.

に存在する水素ガスの影響をも考慮に入れた TDA シミュ レーションなど，鋼中水素の存在状態に関する計算学的 手法による検討に着手したところである ${ }^{14)}$.

\section{$3 \cdot 4$ 水素昇温脱離特性に基づいた余寿命評価}

著者らは, キャビティの成長挙動はいずれの律速過程 16)でも $t^{\mathrm{a}} \sigma^{\mathrm{b}} T^{\mathrm{c}}(t$ : クリープ時間, $\sigma$ : 応力, $T$ : 温度) で表 現できることから，Norton 則も考慮した $\left(t / t_{r}\right)^{\mathrm{a}} \sigma^{\mathrm{B}} T^{\mathrm{c}}\left(t_{\mathrm{r}}\right.$ : ク リープ破断時間）というパラメータを提案した. Gr.91 鋼 のクリープ損傷材の $C_{\mathrm{H}}$ を良好に整理できるような指数を 実験的に求めたところ, $\left(t / t_{\mathrm{r}}\right)^{2} \sigma^{-0.5} T^{-2}$ (以下, $Y_{\mathrm{H}}$ パラメー タ） 9)を得た. 各指数の物理的意味は未だ明らかではないも のの, 本パラメータによってクリープ損傷材の負荷応力や寿 命比を精度良く推定することができた. 同様に, フェライト系ス テンレス鋼においては, $\left(t / t_{\mathrm{r}}\right)^{1} \sigma^{-2} T^{-0.5}$ がクリープ損傷評価のた めの最適なパラメータであることを明らかにした ${ }^{17)}$. 本節では, 低放射化フェライト鋼が Gr.91 鋼と同じラスマルテンサイト組 織を有する鋼種であることから, Gr.91鋼で得られている $Y_{\mathrm{H}}$ パ ラメータ $\left(\left(t / t_{\mathrm{r}}\right)^{2} \sigma^{-0.5} T^{-2}\right)$ を用いたクリープ余寿命評価の可能性 について検討した。

クリープ損傷材で得られた $C_{\mathrm{H}}$ の対数を $Y_{\mathrm{H}}$ の対数に対 してプロットしたものが Fig. 9 である. 両者の関係を求め たところ，次のような近似式で表わすことができた．

$$
\log C_{\mathrm{H}}=1.32\left(\log Y_{\mathrm{H}}\right)^{2}+0.981 \log Y_{\mathrm{H}}+1.65
$$

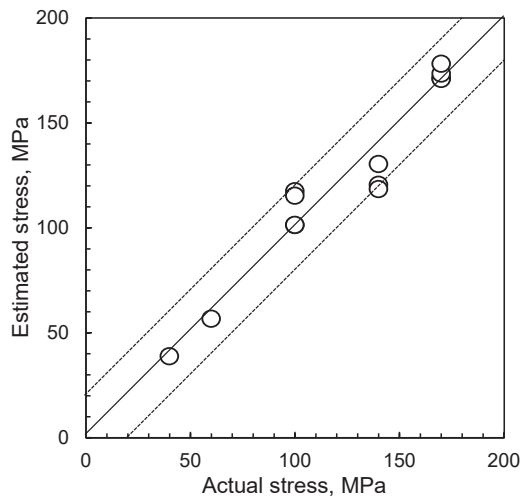

Fig. 12 Comparison of estimated stress with actual one.

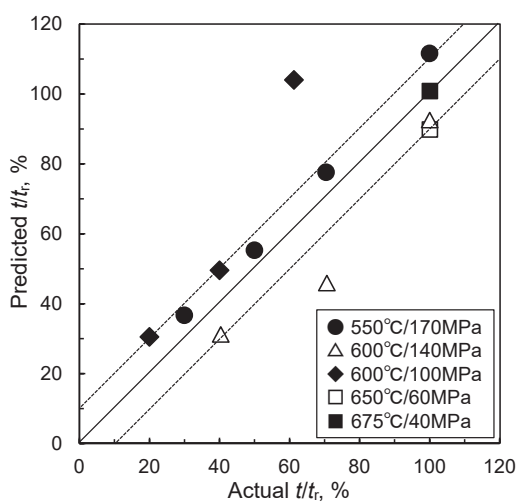

Fig. 13 Comparison of predicted life fraction with actual one.

多少ばらつきはあるが， $Y_{\mathrm{H}}$ パラメータによって $C_{\mathrm{H}}$ を試 験条件に依らず比較的良好に整理できている.これは, 応 力と温度が既知であれば， $C_{\mathrm{H}}$ の計測によってクリープ寿 命比すなわちクリープ余寿命を予測できることを意味し ている.

Fig. 6 からわかるように, $C_{\mathrm{H}}$ は試験応力の低下とともに 高 LMP 側にほぼ平行にシフトしている.この $C_{\mathrm{H}}$ の変化 の応力依存性を定式化するため, $\log C_{\mathrm{H}}=0.2$ mass ppm の ときの LMP $\left(\mathrm{LMP}_{0.2}\right)$ と試験応力の関係を調べた。得ら れた結果を Fig. 10 に示す. データ数は 3 点のみではある が，両者の関係を次式の直線で近似した。

$$
\mathrm{LMP}_{0.2}=-24.4 \sigma+37.5 \times 10^{3}
$$

各クリープ損傷材の $C_{\mathrm{H}}$ を $\mathrm{LMP}-\mathrm{LMP}_{0.2}$ (以下, $\mathrm{LMP}_{\bmod }$ ) に対してプロットしたものを Fig. 11 に示す. ばらつきは

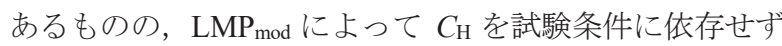
比較的良好に整理できている．両者の関係は次のような 直線で近似することができた.

$$
\log C_{\mathrm{H}}=5.54 \times 10^{-4} \mathrm{LMP}_{\text {mod }}+0.219
$$

クリープ損傷材の試験温度 (LMP) が既知であるとして, 計測された $C_{\mathrm{H}}$ から式(3)と式(2)を用いて各損傷材の試験 応力を推定した. 実際の応力と予測したものの関係を示 したものが Fig. 12 である. 多少ばらつきはあるものの土 
$20 \mathrm{MPa}$ の精度で応力を推定できている．同様に試験温度 が既知であるとして，推定した応力と計測された $C_{\mathrm{H}}$ から 式(1)を用いて各クリープ損傷材のクリープ寿命比 $\left(t / t_{\mathrm{r}}\right)$ を予測した. 実際の寿命比と予測したものの関係を Fig. 13 に示す. 外れている結果もあるが, 大半のものは土10\%の 精度で寿命比を予測できている。この結果は, 対象部位の 温度が既知であれば，TDA で $C_{\mathrm{H}}$ を計測することによっ て，当該箇所の負荷応力とクリープ余寿命を予測できる ことを示唆している.

限られた条件の結果ではあるものの，今回得られた知 見はTDA が核融合炉ブランケット第一壁用低放射化フェ ライト鋼のクリープ損傷検出法として大変有望であるこ とを示唆している. 今後, さらなるデータの拡充に加え, 水素による損傷検出の機序 (水素捕獲メカニズム) を明ら かにすることによって，本手法を同鋼のクリープ余寿命 評価法として確立できるものと期待している.

\section{4 結言}

核融合炉ブランケット第一壁のクリープ余寿命評価へ の水素昇温脱離分析法の適用性を検討することを目的と して, 低放射化フェライト鋼 F82H IEA heat のクリープに 伴う水素昇温脱離特性の変化を調べた. また, 水素昇温脱 離特性変化の機序解明の一環として，電子線照射材と冷 間圧延材を用いて水素昇温脱離特性に及ぼす格子欠陥の 影響を調査した。ささには, 著者らが提案しているキャビ ティ成長則に基づいたパラメータを用いたクリープ余寿 命評価についても検討した。得られた知見をまとめて以 下に示す.

(1) 水素昇温脱離特性は加熱時効にはほとんど影響され ないものの, 試験条件に応じクリープによって変化 する．昇温脱離分析中に放出される水素の量 $\left(C_{\mathrm{H}}\right)$ はクリープの進行 (寿命消費) とともに増加し，それ は低応力長時間側のものほど顕著である。

(2) 電子線照射と冷間圧延でそれぞれ導入した空孔型欠 陥と転位によって水素昇温脱離特性は変化する。し かし，これら格子欠陥に起因した特性変化ではクリ 一プ損傷材における水素昇温脱離特性を説明するこ とはできない。

(3) Gr.91 鋼で提案した $Y_{\mathrm{H}}$ パラメータ $\left(\left(t / t_{\mathrm{r}}\right)^{2} \sigma^{-0.5} T^{-2}\right)$ を 用いることによって $C_{\mathrm{H}}$ を試験条件に依らず良好に 整理することができる。温度が既知であれば， $C_{\mathrm{H}}$ の 計測によりクリープ損傷材の応力を推定することが でき，推定した応力と $C_{\mathrm{H}}$ によって $Y_{\mathrm{H}}$ パラメータか らクリープ寿命比 (余寿命) を予測することが可能で ある。

\section{参 考 文 献}

1) T. Nishitani, T. Yamanishi, H. Tanigawa, M. Nakamichi, T. Nozawa, T. Hoshino and K. Ochiai, "Blanket material and technology developments toward DEMO under the Broader Approach framework", Fusion Engineering and Design, Vol.89, pp.1699-1703 (2014).
2) L. Tan, Y. Katoh, A.-A.F. Tavassoli, J. Henry, M. Rieth, H. Sakasegawa, H. Tanigawa and Q. Huang, "Recent status and improvement of reduced-activation ferritic-martensitic steels for high-temperature service”, Journal of Nuclear Materials, Vol.479, pp.515-523 (2016).

3) C. Cabet, F. Dalle, E. Gaganidze, J. Henry and H. Tanigawa, "Ferritic-martensitic steels for fission and fusion applications", Journal of Nuclear Materials, Vol.523, pp.510-537 (2019).

4) T. Nozawa et al., "Japanese activities of the R\&D on silicon carbide composites in the broader approach period and beyond", Journal of Nuclear Materials, Vol.511, pp.582-590 (2018).

5) T. Muroga, J.M. Chen, V.M. Chernov, R.J. Kurtz and M. Le Flem, "Present status of vanadium alloys for fusion applications", Journal of Nuclear Materials, Vol.455, pp.263268 (2014).

6) K. Saito, T. Hirade and K. Takai, "Hydrogen desorption spectra from excess vacancy-type defects enhanced by hydrogen in tempered martensitic steel showing quasicleavage Fracture", Metallurgical and Materials Transactions A, Vol.50, pp.5091-5102 (2019).

7) S. Komazaki, T. Honda, T. Sakamura, K. Sawada, K. Kimura and Y. Kohno, "Change in hydrogen desorption characteristics of Mod.9Cr-1Mo steel due to creep", Tetsu-toHagané, Vol.96, pp.614-619 (2010).

8) S. Komazaki, T. Tsukamoto, K. Miyata, M. Tabuchi and H. Hongo, "Change in hydrogen desorption characteristic of welded joint of high Cr ferritic steel due to creep", Journal of the Society of Materials Science, Japan, Vol.68, pp.106-113 (2019).

9) H. Yamashita, S. Komazaki, M. Yonemura and M. Igarashi, "Creep remaining-life prediction of Gr.91 steel based on change in hydrogen desorption characteristics", Proceedings of the 49th Symposium on Strength of Materials at High Temperatures, The Committee on High Temperature Strength of Materials, The Society of Materials Science, Japan, pp.111115 (2011).

10) F. Masuyama and N. Komai, "Evaluation of long-term creep rupture strength of tungsten-strengthened advanced 9-12\% $\mathrm{Cr}$ steels", Key Engineering Materials, Vols.171-174, pp.179188 (2000).

11) O. S. Oen, "Cross sections for atomic displacements in solids by fast electrons", (1973), Oak Ridge National Laboratory, Oak Ridge.

12) K. Sato, Q. Xu, D. Hamaguchi, S.S. Huang and T. Yoshiie, "Vacancy migration process in F82H and Fe-Cr binary alloy using positron annihilation lifetime measurement" Journal of Physics: Conference Series, Vol.443, 012031 (2013).

13) T. Horikawa, H. Yamashia, K. Sato and S. Komazaki, "Influence of creep on hydrogen thermal desorption characteristic of high nitrogen ferritic heat-resistant steels", Proceedings of the 53rd Symposium on Strength of Materials at High Temperatures, The Committee on High Temperature Strength of Materials, The Society of Materials Science, Japan, pp.98-102 (2015).

14) T. Kamimura, H. Yamashita, K. Sato, T. Ohyama, Y. Kimoto, Q. Xu and S. Komazaki, "Comparison of hydrogen thermal desorption analysis curves of electron-irradiated F82H and 
creep-ruptured pure $\mathrm{Fe}$ obtained by experiments and simulations", Spallation Materials Technology. accepted.

15) H.-E. Schaefer, K. Maier, M. Weller, D. Herlach, A. Seeger and J. Diehl, "Vacancy formation in iron investigated by positron annihilation in thermal equilibrium", Scripta Metallurgica, Vol.11, pp.803-809 (1977).

16) K. Maruyama and H. Nakashima, "Materials science of high temperature strength, Creep theory and application to practical materials", Chapter 8 (1997), Uchida rokakuho.

17) H. Yamashita, S. Komazaki, K. Sato and K. Kimura, "Creep damage evaluation of heat resistant ferritic stainless steel by hydrogen thermal desorption analysis", Tetsu-to-Hagané, Vol.102, pp.630-637 (2016). 